\title{
Reptiles as potential vectors and hosts of the amphibian pathogen Batrachochytrium dendrobatidis in Panama
}

\author{
Vanessa L. Kilburn" ${ }^{1,4}$, Roberto Ibáñez ${ }^{2}$, David M. Green ${ }^{3, *}$ \\ ${ }^{1}$ Department of Biology, McGill University, 1205 Docteur Penfield Ave., Montréal, Québec H3A 1B1, Canada \\ ${ }^{2}$ Smithsonian Tropical Research Institute, PO Box 0843-03092, Balboa, Ancón, Republic of Panama \\ ${ }^{3}$ Redpath Museum, McGill University, 859 Sherbrooke St. W., Montréal, Québec H3A 2K6, Canada
}

${ }^{4}$ Present address: 3601 Hillcrest Ave., North Vancouver, British Columbia V7R 4B7, Canada

\begin{abstract}
Chytridiomycosis, the disease caused by Batrachochytrium dendrobatidis, is considered to be a disease exclusively of amphibians. However, $B$. dendrobatidis may also be capable of persisting in the environment, and non-amphibian vectors or hosts may contribute to disease transmission. Reptiles living in close proximity to amphibians and sharing similar ecological traits could serve as vectors or reservoir hosts for $B$. dendrobatidis, harbouring the organism on their skin without succumbing to disease. We surveyed for the presence of $B$. dendrobatidis DNA among 211 lizards and 8 snakes at 8 sites at varying elevations in Panama where the syntopic amphibians were at pre-epizootic, epizootic or post-epizootic stages of chytridiomycosis. Detection of $B$. dendrobatidis DNA was done using qPCR analysis. Evidence of the amphibian pathogen was present at varying intensities in 29 of 79 examined Anolis humilis lizards (32\%) and 9 of 101 A. lionotus lizards (9\%), and in one individual each of the snakes Pliocercus euryzonus, Imantodes cenchoa, and Nothopsis rugosus. In general, B. dendrobatidis DNA prevalence among reptiles was positively correlated with the infection prevalence among co-occurring anuran amphibians at any particular site $(r=0.88, p=0.004)$. These reptiles, therefore, may likely be vectors or reservoir hosts for $B$. dendrobatidis and could serve as disease transmission agents. Although there is no evidence of $B$. dendrobatidis disease-induced declines in reptiles, cases of coincidence of reptile and amphibian declines suggest this potentiality. Our study is the first to provide evidence of nonamphibian carriers for $B$. dendrobatidis in a natural Neotropical environment.
\end{abstract}

KEY WORDS: Batrachochytrium dendrobatidis - Chytridiomycosis - Amphibian pathogen · Reservoir host $\cdot$ Lizard $\cdot$ Snake $\cdot$ Reptilia $\cdot$ Neotropics Resale or republication not permitted without written consent of the publisher

\section{INTRODUCTION}

The pathogenic chytrid fungus Batrachochytrium dendrobatidis has been implicated in declines and extirpations of amphibian populations worldwide (Collins \& Crump 2009). B. dendrobatidis invades the epidermal tissue of amphibian skin and causes the disease chytridiomycosis, evidently by disrupting the physiological function of the skin in transporting electrolytes and water (Voyles et al. 2007, 2009, Carver et al. 2010). Chytridiomycosis is fatal to amphibians and is considered to be exclusively an amphibian disease (Berger et al. 1998, Wake 2007). Although it had previously been thought that $B$. dendrobatidis likely feeds on keratin in amphibian skin (Berger et al. 1998, Longcore et al. 1999, Pessier et al. 1999, Green \& Kagarise Sherman 2001), recent work has shown this to be unlikely (Voyles et al. 2011) and 
that proteases secreted by $B$. dendrobatidis apparently degrade proteins such as elastin in the extracellular matrix of skin tissue (Moss et al. 2010).

Batrachochytrium dendrobatidis is highly contagious among amphibians. It is generally held to be a water-borne pathogen, with its motile, flagellated zoospores comprising the infective stage, and can be transmitted via physical contact or zoospore-contaminated water (Berger et al. 1999). Some amphibian species, particularly cane toads Rhinella marina, American bullfrogs Lithobates catesbeianus, African clawed frogs Xenopus laevis and coquis Eleutherodactylus coqui, can harbour high infections of B. dendrobatidis without succumbing to chytridiomycosis. These invasive species may be important reservoir hosts or vectors of the pathogen (Berger et al. 1999, Daszak et al. 2004, Weldon et al. 2004, Beard \& O'Neill 2005) but they do not occur in all areas where native amphibian populations have been stricken with chytridiomycosis. On the contrary, some native Panamanian amphibians such as Centrolene prosoblepon also show some resistance to $B$. dendrobatidis and could act as a reservoir hosts for this pathogen (Woodhams et al. 2006).

It appears that Batrachochytrium dendrobatidis, unlike other chytrids, is probably incapable of living as a saprobe in the natural environment (Johnson \& Speare 2003, Lips et al. 2006, Briggs et al. 2010), though this possibility cannot be ruled out (Longcore et al. 1999, Briggs et al. 2010). B. dendrobatidis zoospores, though, are capable of survival away from an amphibian host. Zoospores are known to persist in the natural environment on rock and boulder substrates, in stream water and in arboreal bromeliads at epizootic sites (Lips et al. 2006, Cossel \& Lindquist 2009, Richards-Zawacki 2010). Under sterile conditions, zoospores can persist on moist bird feathers or boiled snake skin and can be cultivated on tryptone agar or other media (Piotrowski et al. 2004, Symonds et al. 2008). Zoospores have been found to survive for up to $4 \mathrm{wk}$ in tap water, as long as $7 \mathrm{wk}$ in lake water, and 3 mo in sterile moist river sand with no added nutrients (Johnson \& Speare 2003, 2005).

Since it is possible that Batrachochytrium dendrobatidis may not necessarily require an amphibian host for survival, there may exist reservoir hosts or vectors for the pathogen even though none, as yet, have been positively identified. Freshwater shrimp were thought to maintain $B$. dendrobatidis on their carapaces, but this was later found not to be the case (Rowley et al. 2006, 2007). Nevertheless, experimental and genetic evidence has shown that the transfer of pathogens between fish and amphibians is possible (Mao et al. 1999, Kiesecker et al. 2001), with introduced exotic fishes, such as rainbow trout Oncorhynchus mykiss or goldfish Carassius auratus, as the culprits (Gillespie \& Hero 1999, Lips et al. 2005a).

Considering the survivability of Batrachochytrium dendrobatidis outside of aquatic media or amphibian skin, it may not be necessary for a host to be aquatic. $B$. dendrobatidis infection has been observed in completely terrestrial amphibian species (Lips et al. 2006). Although Phillott et al. (2009) were unable to detect $B$. dendrobatidis in a small sample of eastern water dragons Physignathus lesueurii in Australia, reptiles in other localities could nevertheless be vectors or reservoir hosts of $B$. dendrobatidis, particularly those small lizards and forest floor snakes that live in close proximity to amphibians, share similar habitat and microhabitat requirements and have comparable foraging behaviours and prey preferences or, in the case of snakes, that prey upon amphibians. If such reptiles are vectors or reservoir hosts, they should harbour infections of $B$. dendrobatidis that may mirror levels of infection prevalence and intensity by the pathogen among syntopic amphibians.

\section{MATERIALS AND METHODS}

\section{Sampling}

Sampling was conducted in western and central Panama intermittently over a 9 mo period, from February 18 to October 28, 2006, at 8 sites of varying elevation and at pre-epizootic, epizootic or postepizootic stages of chytridiomycosis among anuran amphibians (Table 1, Fig. 1). While seeking out anurans, we opportunistically collected all observed reptiles that were present at the same time and in the same habitats. We subsequently examined epidermal skin swabs from 211 lizards of 13 species and 8 snakes, each of a different species (Table 1). All work with animals was conducted under the auspices of McGill University Animal Use Protocol \#4569 to D. M. Green. Most reptiles examined were identified to species, except for some individuals in the lizard families Sphaerodactylidae and Teiidae, and the snake family Colubridae, as well as one species of arboreal Anolis lizard and one species each of Leptophis and Dipsas snakes. Sampling was conducted by day and night in forest and stream habitats in both the wet and dry seasons to ensure sampling of the 
Table 1. Sample sites in central and western Panama and reptile species examined for Batrachochytrium dendrobatidis DNA. Species that tested positive are in bold

\begin{tabular}{|c|c|c|c|}
\hline \multirow{2}{*}{ Site } & \multirow{2}{*}{ Elevation $(\mathrm{m})$} & \multicolumn{2}{|c|}{ Reptile species examined (n) } \\
\hline & & Lizards & Snakes \\
\hline Cuatro Callitas & 45 & $\begin{array}{c}\text { Anolis sp. (1) } \\
\text { Echinosaura panamensis (2) } \\
\text { Sphaerodactylidae (2) } \\
\text { Anolis humilis (6) } \\
\text { Anolis limifrons (7) } \\
\text { Anolis lionotus (25) }\end{array}$ & Imantodes cenchoa (1) \\
\hline Palmarazo & 135 & $\begin{array}{c}\text { Lepidoblepharis xanthostigma (1) } \\
\text { Anolis limifrons (3) } \\
\text { Anolis lionotus (16) }\end{array}$ & \\
\hline La Rica & 250 & $\begin{array}{l}\text { Anolis humilis (2) } \\
\text { Anolis lionotus (24) }\end{array}$ & $\begin{array}{c}\text { Nothopsis rugosus (1) } \\
\text { Dipsas sp. (1) }\end{array}$ \\
\hline Cerro Trinidad & 540 & $\begin{array}{c}\text { Basiliscus basiliscus (1) } \\
\text { Anolis lionotus (17) }\end{array}$ & Leptophis sp. (1) \\
\hline El Copé & 760 & $\begin{array}{c}\text { Anolis limifrons (1) } \\
\text { Echinosaura panamensis (3) } \\
\text { Anolis humilis (5) } \\
\text { Anolis lionotus (16) }\end{array}$ & $\begin{array}{c}\text { Geophis bellus (1) } \\
\text { Rhadinaea decorata (1) }\end{array}$ \\
\hline Altos de Campana & 860 & $\begin{array}{c}\text { Echinosaura panamensis (1) } \\
\text { Anolis apletophallus (1) } \\
\text { Anolis lionotus (1) } \\
\text { Anolis humilis (6) }\end{array}$ & Colubridae (1) \\
\hline Altos del María & 890 & $\begin{array}{c}\text { Echinosaura panamensis (1) } \\
\text { Ptychoglossus plicatus (1) } \\
\text { Anolis lionotus (2) } \\
\text { Anolis humilis (8) }\end{array}$ & Pliocercus euryzonus (1) \\
\hline Fortuna & 1215 & $\begin{array}{c}\text { Anolis sp. (1) } \\
\text { Anolis capito (1) } \\
\text { Teiidae (2) } \\
\text { Anolis humilis (53) }\end{array}$ & \\
\hline
\end{tabular}

maximum number of diurnal and nocturnal species. To minimize the possibility of resampling individuals, we did not sample any transect more than once. To

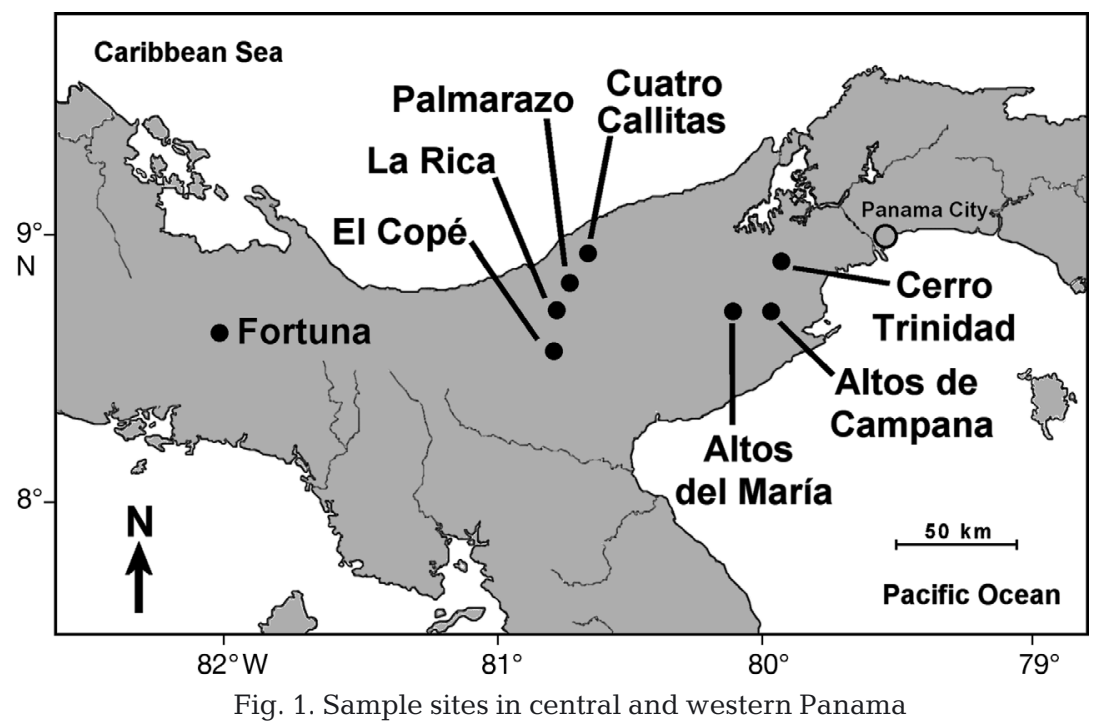

assay for Batrachochytrium dendrobatidis, all reptiles encountered were caught by hand in new individual plastic bags and were swabbed 10 times each on the ventral surface, thighs, and feet using the same sterile technique developed for amphibians and described by Hyatt et al. (2007). Samples were stored at $-20^{\circ} \mathrm{C}$ prior to use.

\section{DNA extraction}

All DNA extractions and purifications of samples were done as described by Kilburn et al. (2011) according to the protocol of Hyatt et al. (2007). After DNA extraction and purification was complete, samples were sent to the RNomics Platform of Genome Quebec for qPCR analysis, as developed by Boyle et al. (2004) 
and adapted for a singlicate assay as described by Kriger et al. (2006). Following Kilburn et al. (2011), we were satisfied that triplicate assays provided no greater quality control over singlicate assays with these methods.

\section{Statistical analyses}

We used raw binary (positive or negative) data on Batrachochytrium dendrobatidis occurrence to determine prevalence, which was calculated as: number of individuals testing positive $\div$ total number of individuals examined. B. dendrobatidis DNA intensity was quantified as the $\log _{10}$ transformed arithmetic mean zoospore equivalent per individual. With these data, we tested for significant differences in infection prevalence and intensity between snakes and lizards at each individual site and between sites. We also compared prevalence and intensity of $B$. dendrobatidis DNA between reptiles and co-occurring amphibians sampled over the same period of time. The relatively small sample sizes for reptiles yielded insufficient power to discriminate between seasons or habitats for any analyses. For comparisons with cooccuring amphibians, we used data on $B$. dendrobatidis DNA prevalence and intensity as presented by Kilburn (2008) and Kilburn et al. (2011).

Statistical analyses comparing Batrachochytrium dendrobatidis prevalence among samples $(\alpha=0.05)$ were done employing Minitab 15.0 Statistical Software for multiple contingency Pearson chi-squared tests for multiple comparisons and Fisher's exact tests for pair-wise comparisons, and software developed by Wessa (2011) for tests employing Pearson product moment correlation. We calculated $95 \%$ confidence intervals (CI) based on a binomial distribution for all prevalence estimates. One-tailed randomization tests were run using the Resampling Stats add-in for Microsoft Excel for all DNA intensity comparisons. For statistical tests involving intensity, we used only positive samples (mean zoospore equivalents $\geq 1.0$ ), with 10000 data permutations for each test, $\alpha=0.05$ and $95 \%$ bootstrap confidence intervals (BCI).

\section{RESULTS}

\section{Prevalence of Batrachochytrium dendrobatidis on reptiles}

Evidence of possible infection by Batrachochytrium dendrobatidis was found in 2 of the 13 species of lizards sampled (Table 1). Affected individuals of Anolis humilis (ground anole) and/or A. lionotus (lion anole) were identified at all sites studied except Palmarazo, where A. humilis was not found. From a total of 79 A. humilis individuals, 25 were found to test positive for $B$. dendrobatidis DNA (Table 2), for a prevalence of $32 \%$ (95\% CI: 22 to $43 \%$ ), whereas only 9 of $101 \mathrm{~A}$. lionotus tested positive, for a prevalence of $9 \%$ (4 to $16 \%$ ). The higher prevalence of $B$. dendrobatidis DNA found in A. humilis was significantly different ( $p<0.001$, Fisher's exact test) compared to its prevalence in A. lionotus, although intensity did not differ (Table 2 ). The overall prevalence of $B$. dendrobatidis DNA among all lizards sampled from all sites was $16 \%$ (11 to $22 \%, \mathrm{n}=211)$.

Batrachochytrium dendrobatidis DNA was also found on 3 individual snakes belonging to 3 of the 8 species examined (Table 1). One Pliocercus euryzonus (Cope's false coral snake) that tested positive was found at the high elevation site of Altos del María (890 m), whereas an individual Imantodes cen-

Table 2. Prevalence (\%) and intensity (mean zoospore equivalents) of Batrachochytrium dendrobatidis DNA among reptiles, with 95\% $\mathrm{CI}$ and probability of difference (prevalence: Fisher's exact test; intensity: randomization test; $\alpha=0.05$ ) between reptiles and syntopic amphibians. * Difference between anurans and reptiles is significant at $\alpha=0.05$

\begin{tabular}{|c|c|c|c|c|c|c|c|c|}
\hline \multirow[t]{2}{*}{ Site } & \multicolumn{3}{|c|}{ Anuran amphibians } & \multicolumn{3}{|c|}{ Reptiles } & \multirow{2}{*}{$\begin{array}{r}\mathrm{p} \\
\text { Prevalence }\end{array}$} & \multirow[b]{2}{*}{ Intensity } \\
\hline & Prevalence & Intensity & $\mathrm{n}$ & Prevalence & Intensity & $\mathrm{n}$ & & \\
\hline Cuatro Callitas & $17.9(9.6-29.1)$ & $694.0(9.4-2008.8)$ & 67 & $6.8(1.4-18.7)$ & $18.7(1.2-65.0)$ & 44 & 0.154 & 0.568 \\
\hline La Rica & $27.6(18.0-39.1)$ & $69.6(6.2-175.3)$ & 76 & $6.9(0.8-22.8)$ & $1.8(1.1-2.4)$ & 29 & $0.032 *$ & 0.334 \\
\hline Cerro Trinidad & $15.1(10.8-20.2)$ & $40.2(14.3-73.8)$ & 245 & $21.1(6.1-45.6)$ & $34.7(1.2-101.2)$ & 19 & 0.510 & 0.310 \\
\hline El Copé & $15.8(6.0-31.3)$ & $2.6(1.7-3.8)$ & 38 & $7.4(0.9-24.3)$ & $1.4(1.1-1.8)$ & 27 & 0.452 & 0.104 \\
\hline Fortuna & $42.3(30.6-54.6)$ & $441.0(4.2-1305.2)$ & 71 & $26.3(15.5-39.7)$ & $9.5(1.6-23.9)$ & 57 & 0.066 & 0.127 \\
\hline All sites combined & $28.2(25.6-30.9)$ & $715.7(230.6-1303.0)$ & 1159 & $16.9(12.2-22.5)$ & $13.1(4.9-22.8)$ & 219 & $<0.001^{*}$ & $0.008^{*}$ \\
\hline
\end{tabular}


choa (blunt-headed tree snake) and one Nothopsis rugosus (rough coffee snake) that tested positive came from the low elevation sites of Cuatro Callitas $(45 \mathrm{~m})$ and La Rica $(250 \mathrm{~m})$, respectively. Prevalence of $B$. dendrobatidis DNA among snakes, with all sites combined, was $38 \%$ (9 to $76 \%, \mathrm{n}=8$ ). Overall B. dendrobatidis prevalence did not differ statistically between lizards and snakes (Table 2).

A considerably greater prevalence of Batrachochytrium dendrobatidis DNA was detected in reptiles (lizards and snakes) at Altos del María compared to other sites. Prevalence of $B$. dendrobatidis DNA among all examined reptiles at Altos del María was $69 \%$ (39 to $91 \%, \mathrm{n}=13$ ) whereas reptiles at other sites showed prevalences of $\leq 26 \%$ (Table 2). Altos del María is a highland site that at the time of sampling was experiencing an epizootic of chytridiomycosis disease among amphibians. Significant differences in prevalence of $B$. dendrobatidis DNA among reptiles between sites were found when data from Altos del María were included in the analysis $\left(\chi^{2}=40.3, p<0.001\right)$ but not between the other 7 sites with Altos del María removed $\left(\chi^{2}=16.0, p=0.014\right)$.

In general, Batrachochytrium dendrobatidis DNA prevalence among reptiles was positively correlated with the infection prevalence among co-occurring anuran amphibians at any particular site $(r=0.88$, $\mathrm{p}$ [2-sided $]=0.004$, Pearson product moment correlation). Both amphibians and reptiles showed their lowest prevalence of $B$. dendrobatidis DNA at Palmarazo and highest prevalence at Altos del María. In 5 of the 8 study sites, prevalence of $B$. dendrobatidis DNA was slightly higher among the anuran amphibians, whereas in 3 study sites it was slightly higher among the reptiles (Table 2). A significant difference in prevalence of $B$. dendrobatidis DNA between reptiles and amphibians was detected only at La Rica, where the reptiles exhibited a significantly lower prevalence than did the syntopic anuran amphibians $(p=0.032$, Fisher's exact test). Overall, however, comparing all reptiles at all sites to co-occurring anuran amphibians, the overall prevalence of $17 \%$ (95\% CI: 12 to $23 \%, n=219$ ) found among reptiles was significantly lower than the $28 \%$ (26 to $31 \%, \mathrm{n}=1159$ ) overall prevalence detected among syntopic anuran amphibians ( $p<0.001$, Fisher's exact test).

\section{Intensity of Batrachochytrium dendrobatidis DNA on reptiles}

Mean intensity of Batrachochytrium dendrobatidis DNA among lizards (Table 2) was 10.6 zoospore equivalents per sample ( $95 \%$ CI: 3.0 to $21.0, \mathrm{n}=34$ ). There was no significant difference in mean intensity between Anolis lionotus (16.7 mean zoospore equivalents; 1.5 to $74.8, \mathrm{n}=9$ ) and A. humilis (8.2 mean zoospore equivalents; 3.4 to $24.5, \mathrm{n}=25$ ). However, mean intensity of $B$. dendrobatidis DNA among snakes was 43.4 zoospore equivalents (1.1 to $65.0, \mathrm{n}=$ $3)$, which was statistically higher than intensity in lizards ( $p=0.035$, Randomization test). With lizards and snakes combined, no significant difference in intensity of $B$. dendrobatidis DNA was found between sites.

We found no significant difference in Batrachochytrium dendrobatidis DNA intensity between reptiles and syntopic anuran amphibians at any site, including Altos del María (Table 2). However, when data from all sites were combined, reptiles showed an overall mean intensity of 13.1 zoospore equivalents per sample ( 4.9 to $22.8, \mathrm{n}=37$ ), which was significantly lower than the infection intensity of 715.7 mean zoospore equivalents (230.6 to 1303.0, $\mathrm{n}=327$ ) found among co-occurring anuran amphibians ( $\mathrm{p}=$ 0.008 , Randomization test).

No individual reptile that tested positive for Batrachochytrium dendrobatidis DNA showed either the symptoms of chytridiomycosis disease or the elevated levels of infection intensity notable in anuran amphibians stricken with chytridiomycosis (Kilburn et al. 2011).

\section{DISCUSSION}

Batrachochytrium dendrobatidis is clearly not exclusive to amphibians. We have shown that, in Panama, lizards and snakes will harbour $B$. dendrobatidis DNA at non-pathological levels of prevalence and intensity that are comparable to those found among anuran amphibians that are not showing signs of chytriomycosis disease (Kilburn et al. 2011). Without histology, we cannot say that we have proven the presence of $B$. dendrobatidis infection or the presence of infective zoospores on the reptiles, but the assays we used are routinely considered diagnostic for $B$. dendrobatidis infection in amphibians and, therefore, our findings indicate that infection is highly plausible.

Batrachochytrium dendrobatidis DNA is not uniformly present in those species of reptiles that may carry it. For example, we detected $B$. dendrobatidis DNA in Anolis lionotus from 4 sites, but not among 16 specimens from Palmarazo or 24 specimens from La Rica (Table 1). Anolis humilis tested positive for $B$. 
dendrobatidis DNA in 5 of the 6 sites where the species was present. Compared to $A$. lionotus and $A$. humilis, our sample sizes were small for those species of lizards that did not test positive for B. dendrobatidis DNA. Thus, Phillott et al. (2009) may not have detected $B$. dendrobatidis DNA in Australian eastern water dragons simply because they sampled only 15 lizards from a single site, and not necessarily due to any inability of $B$. dendrobatidis DNA to persist on water dragon skin.

The species of reptiles we found to carry the DNA signature of Batrachochytrium dendrobatidis infection have habitat preferences and/or behaviours that may readily put them in contact with the pathogen. Anolis humilis is a terrestrial lizard found on the wet leaf litter of the forest floor (Savage 2002) and $A$. lionotus is semiaquatic, exclusively found along streams (Campbell 1973). Both Nothopsis rugosus and Pliocercus euryzonus are terrestrial leaf litter snakes (Savage 2002, Solórzano 2004), and Imantodes cenchoa, though primarily arboreal, sometimes is seen on the forest floor and is known to sleep hidden in hollow sections of trees and other plants, in bromeliads or in leaf litter and fallen vegetation (Myers 1982). Unlike the 2 insectivorous lizards, the snakes could also become infected with $B$. dendrobatidis in the act of subduing and ingesting their prey, which consists of salamanders, frogs and lizards.

By potentially maintaining the pathogen in the environment without succumbing to the disease, these reptiles may be important vectors or reservoir hosts for Batrachochytrium dendrobatidis. As carriers of the pathogen, they may allow virulent strains of $B$. dendrobatidis to spread. Significantly, reptiles at Altos del María exhibited elevated levels of $B$. dendrobatidis DNA prevalence at a time when syntopic amphibians were succumbing to epizootic chytridiomycosis disease. The observed enzootic persistence of $B$. dendrobatidis in the environment even after susceptible amphibian populations have succumbed to chytridiomycosis (Lips et al. 2005b, Kilburn et al. 2011) may also be abetted by reptiles serving as reservoir hosts.

Although the skin of reptiles is evidently capable of carrying Batrachochytrium dendrobatidis DNA under natural field conditions, it remains to be seen whether $B$. dendrobatidis can complete its life cycle on reptile integument, or whether it can persist on reptiles indefinitely in the absence of amphibian hosts. Reptile skin is quite unlike the skin of amphibians. It is highly keratinised, non-respiratory, relatively impermeable to water and has little physiological role in maintaining electrolyte balance.
Batrachochytrium dendrobatidis produces an assortment of proteolytic enzymes (Symonds et al. 2008, Moss et al. 2010). Though there is, as yet, no evidence among reptiles of the lethal, epizootic chytridiomycosis that has afflicted amphibian populations in many parts of the world, it does not follow that $B$. dendrobatidis infection in reptiles, should it occur, is necessarily benign.

Like amphibians, populations of lizards and snakes are in decline throughout the world (Gibbons et al. 2000), including locations in Central America (Pounds et al. 1999, Greenbaum \& Komar 2005, Whitfield et al. 2007) and at sites where Batrachochytrium dendrobatidis, and chytridiomycosis, has been detected in co-occurring amphibians (Reading et al. 2010, Sinervo et al. 2010). Declines in species of snakes that rely on adult frogs and frog egg masses as their primary prey may be related to chytridiomycosis-induced losses of amphibian biomass (Whiles et al. 2006). Reasoning, though, that chytridiomycosis was strictly a disease of amphibians, Whitfield et al. (2007), Wake (2007) and Sinervo et al. (2010) attributed declines in reptile abundance in Central America, in general, to the effects of climate change. We cannot conclude from our results that $B$. dendrobatidis is a virulent reptile pathogen, or that it causes disease-induced decline in reptile populations, but our evidence that reptiles do carry $B$. dendrobatidis DNA in neotropical localities where both reptiles and amphibians have declined warrants some concern.

Acknowledgements. We thank J. Suraci, J. Ray, G. Reina, A. Crawford, V. Flechas, K. Turner, D. Turner, S. Oestreicher, E. Trimble, D. Raab, P. McGaw, A. Kilburn and C. Jaramillo for help in the field; O. Sanjur and E. Bermingham for advice and support for laboratory work at the STRI Naos lab in Panama; A. Bramard (Genome Quebec) and C. Brisson for help with the molecular analyses; and the Autoridad Nacional del Ambiente de Panamá for expediting research permits. This research was supported by an NSERC Canada CGS M scholarship to V.L.K. and an NSERC Canada Discovery Grant to D.M.G.

\section{LITERATURE CITED}

Beard KH, O'Neill EM (2005) Infection of an invasive frog Eleutherodactylus coqui by the chytrid fungus Batrachochytrium dendrobatidis in Hawaii. Biol Conserv 126: 591-595

Berger L, Speare R, Daszak P, Green DE and others (1998) Chytridiomycosis causes amphibian mortality associated with population declines in the rain forests of Australia and Central America. Proc Natl Acad Sci USA 95: 9031-9036

Berger L, Speare R, Hyatt AD (1999) Chytrid fungi and amphibian declines: overview, implications and future 
directions. In: Campbell A (ed) Declines and disappearances of Australian frogs. Environment Australia, Canberra, p 23-33

Boyle DG, Boyle DB, Olsen V, Morgan JAT, Hyatt AD (2004) Rapid quantitative detection of chytridiomycosis (Batrachochytrium dendrobatidis) in amphibian samples using real-time Taqman PCR Assay. Dis Aquat Org 60:141-148

Briggs CJ, Knapp RA, Vredenburg VT, Vance T (2010) Enzootic and epizootic dynamics of the chytrid fungal pathogen of amphibians. Proc Natl Acad Sci USA 107: 9695-9700

Campbell HW (1973) Ecological observations on Anolis lionotus and Anolis poecilopus (Reptilia, Sauria) in Panama. Am Mus Novit 2516:1-29

> Carver S, Bell BD, Waldman B (2010) Does chytridiomycosis disrupt amphibian skin function? Copeia 2010:487-495

Collins JP, Crump ML (2009) Extinction in our times: global amphibian decline. Oxford University Press, New York, NY

Cossel OJ Jr, Lindquist ED (2009) Batrachochytrium dendrobatidis in arboreal and lotic water sources in Panama. Herpetol Rev 40:45-47

Daszak P, Strieby A, Cunningham AA, Longcore J, Brown CC, Porter D (2004) Experimental evidence that the bullfrog (Rana catesbeiana) is a potential carrier of chytridiomycosis, an emerging fungal disease of amphibians. J Herpetol 14:201-207

> Gibbons JW, Scott DE, Ryan TJ, Buhlmann KA and others (2000) The global decline of reptiles, déjà vu amphibians. Bioscience 50:653-666

Gillespie GR, Hero JM (1999) Potential impacts of introduced fish and fish translocations on Australian amphibians. In: Campbell A (ed) Declines and disappearances of Australian frogs. Environment Australia, Canberra, p 131-144

> Green DE, Kagarise Sherman C (2001) Diagnostic histological findings in Yosemite toads (Bufo canorus) from a dieoff in the 1970's. J Herpetol 35:92-103

Greenbaum E, Komar O (2005) Threat assessment and conservation prioritization of the herpetofauna of El Salvador. Biodivers Conserv 14:2377-2395

Hyatt AD, Boyle DG, Olsen V, Boyle DB and others (2007) Diagnostic assays and sampling protocols for the detection of Batrachochytrium dendrobatidis. Dis Aquat Org 73:175-192

> Johnson ML, Speare R (2003) Survival of Batrachochytrium dendrobatidis in water: quarantine and disease control implications. Emerg Infect Dis 9:922-925

Johnson ML, Speare R (2005) Possible modes of dissemination of the amphibian chytrid Batrachochytrium dendrobatidis in the environment. Dis Aquat Org 65:181-186

Kiesecker JM, Blaustein AR, Miller CL (2001) Transfer of a pathogen from fish to amphibians. Conserv Biol 15: 1064-1070

Kilburn VL (2008) Persistence and prevalence of the enzootic chytrid fungus, Batrachochytrium dendrobatidis, in relation to amphibian population decline in Panama. MSc. thesis, McGill University, Montreal

Kilburn VL, Ibáñez R, Sanjur O, Bermingham E, Suraci JP, Green DM (2011) Ubiquity of the pathogenic chytrid fungus, Batrachochytrium dendrobatidis, in anuran communities in Panamá. EcoHealth 7:537-548

Kriger KM, Hero JM, Ashton KJ (2006) Cost efficiency in the detection of chytridiomycosis using PCR assay. Dis Aquat Org 71:149-154
Lips KR, Burrowes PA, Mendelson JR, Parra-Olea G (2005a) Amphibian declines in Latin America: widespread population declines, extinctions, and impacts. Biotropica 37: 163-165

> Lips KR, Burrowes PA, Mendelson JR, Parra-Olea G (2005b) Amphibian population declines in Latin America: a synthesis. Biotropica 37:222-226

Lips KR, Brem F, Brenes R, Reeve JD and others (2006) Emerging infectious disease and the loss of biodiversity in a Neotropical amphibian community. Proc Natl Acad Sci USA 103:3165-3170

- Longcore JE, Pessier AP, Nichols DK (1999) Batrachochytrium dendrobatidis gen. et sp. nov., a chytrid pathogenic to amphibians. Mycologia 91:219-227

Mao J, Green DE, Fellers G, Chincar VG (1999) Molecular characterization of iridoviruses isolated from sympatric amphibians and fish. Virus Res 63:45-52

> Moss AS, Carty N, San Francisco MJ (2010) Identification and partial characterization of an elastolytic protease in the amphibian pathogen Batrachochytrium dendrobatidis. Dis Aquat Org 92:149-158

Myers CW (1982) Blunt-headed vine snakes (Imantodes) in Panama, including a new species and other revisionary notes. Am Mus Novit 2738:1-50

> Pessier AP, Nichols DK, Longcore JE, Fuller JS (1999) Cutaneous chytridiomycosis in poison dart frogs (Dendrobates spp.) and White's tree frogs (Litoria caerulea). J Vet Diagn Invest 11:194-199

Phillott AD, Garland S, Skerratt LF (2009) Eastern water dragons (Physignathus lesueurii) are not important alternate hosts of the frog chytrid fungus Batrachochytrium dendrobatidis. Herpetol Conserv Biol 4:379-383

> Piotrowski JS, Annis SL, Longcore JE (2004) Physiology of Batrachochytrium dendrobatidis, a chytrid pathogen of amphibians. Mycologia 96:9-15

Pounds JA, Fogden MPL, Campbell JH (1999) Biological response to climate change on a tropical mountain. Nature 398:611-615

Reading CJ, Luiselli LM, Akani GC, Bonnet X and others (2010) Are snake populations in widespread decline? Biol Lett 6:777-780

Richards-Zawacki CL (2010) Thermoregulatory behaviour affects prevalence of chytrid fungal infection in a wild population of Panamanian golden frogs. Proc R Soc Lond B 277:519-528

Rowley JJL, Alford RA, Skerratt LF (2006) The amphibian chytrid Batrachochytrium dendrobatidis occurs on freshwater shrimp in rain forest streams in Northern Queensland, Australia. EcoHealth 3:49-52

> Rowley JJL, Hemingway VA, Alford RA, Waycott M, Skerratt LF, Campbell R, Webb R (2007) Experimental infection and repeat survey data indicate the amphibian chytrid Batrachochytrium dendrobatidis may not occur on freshwater crustaceans in Northern Queensland, Australia. EcoHealth 4:31-36

Savage JM (2002) The amphibians and reptiles of Costa Rica: a herpetofauna between two continents, between two seas. University of Chicago Press, Chicago, IL

Sinervo B, Méndez-de-la-Cruz F, Miles DB, Heulin B and others (2010) Erosion of lizard diversity by climate change and altered thermal niches. Science 328: 894-899

Solórzano A (2004) Snakes of Costa Rica: distribution, taxonomy, and natural history. Instituto Nacional de la Biodiversidad (INBio), Santo Domingo de Heredia 
Symonds EP, Trott DJ, Bird PS, Mills P (2008) Growth characteristics and enzyme activity in Batrachochytrium dendrobatidis isolates. Mycopathologia 166:143-147

Voyles J, Berger L, Young S, Speare R and others (2007) Electrolyte depletion and osmotic imbalance in amphibians with chytridiomycosis. Dis Aquat Org 77:113-118

> Voyles J, Young S, Berger L, Campbell C and others (2009) Pathogenesis of chytridiomycosis, a cause of catastrophic amphibian declines. Science 326:582-585

Voyles J, Rosenblum EB, Berger L (2011) Interactions between Batrachochytrium dendrobatidis and its amphibian hosts: a review of pathogenesis and immunity. Microbes Infect 13:25-32

Wake DB (2007) Climate change implicated in amphibian and lizard declines. Proc Natl Acad Sci USA 104: 8201-8202

Weldon C, du Preez LH, Hyatt AD, Muller R, Speare R

Editorial responsibility: Cynthia Carey,

Boulder, Colorado, USA
(2004) Origin of the amphibian chytrid fungus. Emerg Infect Dis 10:2100-2105

Wessa P (2011) Free Statistics Software, version 1.1.23-r6. Office for Research Development and Education, available at www.wessa.net

Whiles MR, Lips KR, Pringle CM, Kilham SS and others (2006) The effects of amphibian population declines on the structure and function of Neotropical stream ecosystems. Front Ecol Environ 4:27-34

Whitfield SM, Bell KE, Philippi T, Sasa M and others (2007) Amphibian and reptile declines over 35 years at $\mathrm{La}$ Selva, Costa Rica. Proc Natl Acad Sci USA 104: 8352-8356

Woodhams DC, Voyles J, Lips KR, Carey C, Rollins-Smith LAA (2006) Predicted disease susceptibility in a Panamanian amphibian assemblage based on skin peptide defenses. J Wildl Dis 42:207-218

Submitted: April 18, 2011; Accepted: August 31, 2011

Proofs received from author(s): November 7, 2011 